Christina Wallrabenstein · Bernhard Schink

\title{
Evidence of reversed electron transport in syntrophic butyrate or benzoate oxidation by Syntrophomonas wolfei and Syntrophus buswellit
}

Received: 2 March 1994 / Accepted: 20 April 1994

\begin{abstract}
Syntrophomonas wolfei and Syntrophus buswellii were grown with butyrate or benzoate in a defined binary coculture with Methanospirillum hungatei. Both strains also grew independent of the partner bacteria with crotonate as substrate. Localization of enzymes involved in butyrate oxidation by $S$. wolfei revealed that ATP synthase, hydrogenase, and butyryl-CoA dehydrogenase were at least partially membrane-associated whereas 3hydroxybutyryl-CoA dehydrogenase and crotonase were entirely cytoplasmic. Inhibition experiments with copper chloride indicated that hydrogenase faced the outer surface of the cytoplasmic membrane. Suspensions of butyrate- or benzoate-grown cells of either strain accumulated hydrogen during oxidation of butyrate or benzoate to a low concentration that was thermodynamically in equilibrium with calculated reaction energetics. The protonophore carbonylcyanide $m$-chlorophenyl-hydrazone (CCCP) and the proton-translocating ATPase inhibitor $N, N^{\prime}$ dicyclohexylcarbodiimide (DCCD) both specifically inhibited hydrogen formation from butyrate or benzoate at low concentrations, whereas hydrogen formation from crotonate was not affected. A menaquinone was extracted from cells of $S$. wolfe $i$ and $S$. buswellii grown syntrophically in a binary methanogenic culture. The results indicate that a proton-potential-driven process is involved in hydrogen release from butyrate or benzoate oxidation.
\end{abstract}

Key words Syntrophic oxidation - Butyrate - Benzoate $\mathrm{H}_{2}$ formation - Syntrophomonas wolfei $\cdot$ Syntrophus buswellii

Abbreviations $B E S$ Bromoethanesulfonate $\cdot C C C P$ Carbonyl cyanide- $m$-chlorophenyl-hydrazone $\cdot D C C D$ $N, N^{\prime}$ dicyclohexylcarbodiimide $\cdot D C P I P$ Dichlorophenol indophenol - PMS Phenazine methosulfate

C. Wallrabenstein - B. Schink (적

Fakultät für Biologie, Universität Konstanz, Postfach 5560, D-78434 Konstanz, Germany

Tel +49-7531-882140, Fax +49-7531-882966,

e-mail Bernhard Schink@uni-konstanz.de

\section{Introduction}

Fermentation of butyrate or benzoate to acetate $\left(\mathrm{CO}_{2}\right)$ and hydrogen are endergonic reactions under standard conditions [all calculations are based on Thauer et al. (1977), with $\mathrm{CO}_{2}$ and $\mathrm{H}_{2}$ in the gaseous state]:

$$
\begin{aligned}
& \text { butyrate }{ }^{-}+2 \mathrm{H}_{2} \mathrm{O} \rightarrow 2 \text { acetate }^{-}+\mathrm{H}^{+}+2 \mathrm{H}_{2} \\
& \Delta \mathrm{G}^{0^{\prime}}=+48.3 \mathrm{~kJ} \text { per mol butyrate } \\
& \text { benzoate }{ }^{-}+6 \mathrm{H}_{2} \mathrm{O} \rightarrow 3 \text { acetate }^{-}+2 \mathrm{H}^{+}+\mathrm{CO}_{2}+3 \mathrm{H}_{2} \\
& \Delta \mathrm{G}^{0^{\prime}}=+49.5 \mathrm{~kJ} \text { per mol benzoate. }
\end{aligned}
$$

Degradation of both compounds becomes feasible only at low hydrogen partial pressure $\left(10^{-4}-10^{-5} \mathrm{~atm}\right.$; Schink 1992), which can be maintained by hydrogen-oxidizing anaerobes such as methanogenic bacteria (Zehnder 1978; Dolfing 1988). The pathways of butyrate and benzoate degradation in these bacteria have been at least tentatively elucidated (see Schink 1992). The energetically most difficult electron transfer steps are the oxidations of the saturated acid esters butyryl-CoA or glutaryl-CoA to the respective unsaturated compounds. The electrons released in the butyryl-CoA dehydrogenase reaction $\left(E_{0}^{\prime}=-125\right.$ $\mathrm{mV}$; Gustafson et al. 1986) and glutaryl-CoA dehydrogenase, for which a similar redox potential is assumed, are used to reduce protons to molecular hydrogen $\left(\mathrm{E}_{0}=-414\right.$ $\mathrm{mV}$ ). Even at $10^{-4} \mathrm{~atm}$ hydrogen, the redox potential of the couple $2 \mathrm{H}^{+} / \mathrm{H}_{2}$ is still $-295 \mathrm{mV}$ and is much lower than that of the electron donor. It has been hypothesized, therefore, that part of the ATP gained by substrate level phosphorylation during butyrate oxidation has to be spent in a reversed electron transport step to shift these electrons to a lower redox potential (Thauer and Morris 1984). Similar problems arise with oxidation of saturated intermediates in syntrophic benzoate degradation, and involvement of reversed electron transport in this oxidation also has been postulated (Schink 1992). However, experimental evidence of such energy-driven processes in syntrophic butyrate or benzoate oxidation has never been provided.

Syntrophomonas wolfei was the first syntrophic butyrate-degrader isolated in a binary methanogenic cocul- 
ture (McInerney et al. 1981). The pathway of butyrate oxidation has been elucidated by enzyme measurements in cell-free extracts of this culture (Wofford et al. 1986). The only syntrophic culture isolated with benzoate as substrate, Syntrophus buswellii, could be obtained in a binary mixed culture only with Desulfovibrio sp., or in a ternary methanogenic coculture with Methanospirillum hungatei and Desulfovibrio sp. (Mountfort et al. 1984).

The aim of the present study was to check for a possible involvement of reversed electron transport in syntrophic oxidation of butyrate and benzoate, and its possible association with membrane-bound energy-transducing components. Such studies required defined binary cocultures of both syntrophic bacteria with methanogens as the sole partner bacteria.

\section{Materials and methods}

Organisms and cultivation

The binary methanogenic coculture Syntrophomonas wolfei (DSM 2245 B) and the ternary methanogenic coculture Syntrophus buswellii, which also contained Desulfovibrio sp. (DSM 2612 B), were obtained from the Deutsche Sammlung von Mikroorganismen GmbH (Braunschweig, Germany). Methanospirillum hungate $i$ strain SK was kindly provided by Prof. Dr. F. Widdel (Bremen, Germany).

All procedures for cultivation were as previously described (Widdel and Pfennig 1981). The mineral medium contained $0.5 \mathrm{~g}$ $\mathrm{NaCl}$ and $0.4 \mathrm{~g} \mathrm{MgCl}_{2} \times 6 \mathrm{H}_{2} \mathrm{O}$ per 1, was buffered with $30 \mathrm{mM}$ bicarbonate, and contained $1 \mathrm{~m} M$ sodium sulfide as reducing agent, trace element solution SL 10 (Widdel et al. 1983), selenitetungstate solution (Tschech and Pfennig 1984), and a 7-vitamin solution (Pfennig 1978). The $\mathrm{pH}$ was adjusted to 7.2-7.4. Addition of small amounts $(50-100 \mu M)$ of sodium dithionite helped to shorten growth lags. Acetate, butyrate, crotonate, and benzoate were added from autoclaved neutral $1.0 \mathrm{M}$ stock solutions. $M$. hungatei strain SK was grown in medium containing $5 \mathrm{~m} M$ acetate under $\mathrm{H}_{2} / \mathrm{CO}_{2}(80 / 20)$. For growth of $S$. wolfei, $0.05 \%$ (w/v) yeast extract was added to the medium. Cultures (1 1) were grown in 1200 -ml infusion bottles under $\mathrm{N}_{2} / \mathrm{CO}_{2}(90 / 10)$ with $20 \mathrm{mM}$ butyrate, $10 \mathrm{~m} M$ benzoate, or $10 \mathrm{~m} M$ crotonate. Growth at $28^{\circ} \mathrm{C}$ was followed measuring turbidity at $578 \mathrm{~nm}$.

\section{Preparation of cell suspensions}

Cultures at the end of the logarithmic growth phase were transferred into oxygen-free centrifuge vials in an anoxic chamber (Coy, Ann Arbor, Mich., USA) and centrifuged at $8000 \times g$ for 30 min. Cells were suspended in $50 \mathrm{~m} M$ Mops/KOH buffer (pH 7.0) containing $5 \mathrm{mM} \mathrm{MgCl}$, and were transferred into $120-\mathrm{ml}$ infusion bottles. Cell suspensions in the infusion bottles were washed twice under anoxic conditions in the same buffer by centrifugation $(20 \mathrm{~min}, 2100 \times \mathrm{g})$. Cell suspensions $\left(\mathrm{OD}_{578}=8-10\right)$ were stored under $\mathrm{N}_{2}$ on ice.

\section{Preparation of cell-free extracts and membrane fractions}

Cells were harvested as described above, washed twice in anoxic potassium phosphate buffer $(50 \mathrm{~m} M, \mathrm{pH}$ 7.2) containing $5 \mathrm{~m} M$ $\mathrm{MgCl}_{2}$, and resuspended in $3 \mathrm{ml}$ of the same buffer. The suspension was passed 2-3 times through a French-pressure cell (140 $\mathrm{MPa}$ ). Cell debris and intact cells were removed by centrifugation $(5000 \times g, 15 \mathrm{~min})$. The supernatant (crude cell extract) was centrifuged under anoxic conditions $(100,000 \times g, 1 \mathrm{~h})$. The $100,000 \times g$ supernatant (soluble fraction) was removed and stored anoxically on ice. The pellet (membrane fraction) was washed once in potassium phosphate buffer $(50 \mathrm{~m} M, \mathrm{pH} 7.2$, with $5 \mathrm{mM} \mathrm{MgCl})$ and resuspended in the same volume of buffer as the original crude extract.

\section{Selective cell lysis with mutanolysin or lysozyme}

Mutanolysin, a bacteriolytical enzyme from Streptomyces globiformis (Yokogawa et al. 1974), was used at activities of 50-150 U/mg protein in $100 \mathrm{mM}$ anoxic potassium phosphate buffer $(\mathrm{pH}$ 6.2 ). Cells were incubated for $30 \mathrm{~min}$ at $37^{\circ} \mathrm{C}$. Cell lysis was checked microscopically and by measuring enzyme activities in the supernatant after removal of intact cells by centrifugation ( $5000 \times g, 15 \mathrm{~min})$. Selectivity of lysis was checked by treatment of a pure culture of $M$. hungatei grown with $\mathrm{H}_{2} / \mathrm{CO}_{2}$ under the same conditions. Fluorimetric determination of the methanogenic cofactor $F_{420}$ was used as an indicator of contamination by cytoplasmic components of the methanogenic partner bacterium, using an Eppendorf $1101 M$ photometer with fluorescence capability (excitation wavelengths 405 and $436 \mathrm{~nm}$ ). Additional controls were run with cell extracts prepared by French-press treatment ( 3 times, $136 \mathrm{MPa}$ ). Lysozyme treatment was performed anoxically in Tris/HCl buffer $(10 \mathrm{~m} M$, pH 8.0$)$ containing $0.5 \mathrm{mg}$ lysozyme and $0.4 \mathrm{mg}$ EDTA per $\mathrm{ml}(2.5-5 \mu \mathrm{g}$ lysozyme per mg protein). Suspensions were incubated at $37^{\circ} \mathrm{C}$ for $30 \mathrm{~min}$ and cell lysis was checked microscopically.

\section{Enzyme measurements}

All enzyme measurements were performed at $25^{\circ} \mathrm{C}$ in $1 \mathrm{~cm} \mathrm{cu}-$ vettes under a $\mathrm{N}_{2}$ atmosphere using a spectrophotometer model 100-40 (Hitachi, Tokyo, Japan). Additions were made with microliter syringes.

Butyryl-CoA dehydrogenase (EC 1.3.99.3; modified after acylCoA dehydrogenase, Bergmeyer 1974) was measured with dichlorophenol indophenol (DCPIP) as electron acceptor in the presence of phenazine methosulfate (PMS) as intermediary electron carrier. The assay mixture contained $50 \mathrm{mM}$ potassium phosphate buffer $(\mathrm{pH} 7.5), 0.2 \mathrm{mM}$ DCPIP $\left(\varepsilon_{600}=20.0 \mathrm{mM}^{-1} \mathrm{~cm}^{-1}\right), 0.1$ $\mathrm{m} M$ PMS, and $0.1 \mathrm{~m} M$ butyryl-CoA.

Glutaryl-CoA dehydrogenase (EC 1.3.99.7) was determined in a way similar to succinate dehydrogenase (Stams et al. 1984) with $\mathrm{K}_{3} \mathrm{Fe}(\mathrm{CN})_{6}\left(\varepsilon_{420}=0.9 \mathrm{~m} M^{-1} \mathrm{~cm}^{-1}\right)$ as electron acceptor in the presence of PMS. The assay mixture contained $50 \mathrm{mM}$ potassium

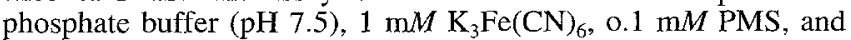
$0.05 \mathrm{~m} M$ glutaryl-CoA.

3-Hydroxybutyryl-CoA dehydrogenase (EC 1.1.1.157) was determined following decrease of NADH at $365 \mathrm{~nm}$ in the presence of $S$-acetoacetyl-CoA (Bergmeyer 1974). The assay mixture contained $12.5 \mathrm{~m} M$ sodium pyrophosphate buffer ( $\mathrm{pH} 7.3), 0.25 \mathrm{mM}$ $\mathrm{NADH}$, and $1 \mathrm{~m} M S$-acetoacetyl-CoA.

Hydrogenase (EC 1.12.1.2) activity was measured following benzyl viologen $\left(\varepsilon_{578}=8.65 \mathrm{~m} M^{-1} \mathrm{~cm}^{-1}\right)$ reduction with hydrogen (Diekert and Thauer 1978).

ATPase (EC 3.6.1.3) activity was determined following NADH oxidation in the presence of ATP, phosphoenolpyruvate, pyruvate kinase, and lactate dehydrogenase (modified after Vogel and Steinhart 1976). The assay mixture contained $100 \mathrm{~m} M$ potassium phosphate buffer ( $\mathrm{pH} 7.6), 5 \mathrm{~m} M \mathrm{MgCl}_{2}, 1 \mathrm{~m} M$ NADH, $2 \mathrm{~m} M$ phosphoenolpyruvate, $5 \mathrm{U}$ pyruvate kinase, and $20 \mathrm{U}$ lactate dehydrogenase. The reaction was started by addition of $5 \mathrm{mM}$ ATP.

\section{Hydrogen release experiments}

Assays were performed at $37^{\circ} \mathrm{C}$ in $\mathrm{N}_{2}$-flushed 4 -ml vials closed with butyl rubber septa. Fresh cell suspension $(1 \mathrm{ml})$ was added by syringe. The assay mixture contained $5 \mathrm{mM}$ bromoethanesulfonate (BES) to inhibit methanogenesis. Before the reaction was started 
by addition of Na-butyrate, Na-benzoate, or Na-crotonate $(10 \mathrm{~m} M$ final concentration), background hydrogen formation was followed for 10-30 min until a constant level was reached. For tests with DCCD, cell suspensions were preincubated for $15 \mathrm{~min}$ with an ethanolic solution of the inhibitor ( $25 \mathrm{nmol}$ per $\mathrm{mg}$ protein). Controls were performed with pure ethanol. CCCP (10 nmol per mg protein) was added to the reaction mixture when hydrogen accumulation had already started.

Localization of hydrogenase activity through copper inhibition

Cell suspensions $\left(\mathrm{OD}_{578}\right.$ approx. 3.0) were prepared as described above, preincubated anoxically with $1 \mathrm{mM} \mathrm{CuCl}$ for $10-15 \mathrm{~min}$, and then used for hydrogenase assay (after Cypionka and Dilling 1986). Similar experiments with crude French-press extract served as controls.

\section{Cytochromes and quinones}

Cytochromes were determined in cell-free extracts and membrane preparations were obtained by ultracentrifugation as described above. Redox difference spectra (dithionite-reduced minus air-oxidized) were measured with a Uvikon 860 spectrophotometer (Kontron, Zürich, Switzerland).

Quinones were extracted from dry cells (Collins 1985) with petrol ether: methanol $(2: 1 \mathrm{v} / \mathrm{v})$ as solvent. The purified quinones were dissolved in isopropanol and examined by high performance liquid chromatography (Kroppenstedt 1985).

Chemical analyses

Fatty acids and crotonate were assayed by gas chromatography as described previously (Platen and Schink 1987). Hydrogen concentrations $\left(\leq 10^{-3}\right.$ bar) were determined by gas chromatography with a Mercury Reduction Gas Detector (Wolters, Dïsseldorf, Germany). Gases were separated at room temperature on a $1.8 \mathrm{~m} \times 2$ mm column packed with $5 \AA$ molecular sieve (Serva, Heidelberg). Protein was quantified by a micro assay after Bradford (1976) using bovine serum albumin as standard.

\section{Chemicals}

All chemicals were of reagent grade quality and were obtained from Fluka (Neu-Ulm), Sigma (Deisenhofen), and Merck (Darmstadt). Biochemicals were from Boehringer (Mannheim), and Sigma (Deisenhofen). Mutanolysin was obtained from Sigma.

\section{Results}

Growth of Syntrophus buswellii in defined mineral medium

S. buswellii grew with benzoate in defined mineral medium. After repeated transfer into this medium, the contaminating Desulfovibrio sp. was diluted out. Since $S$. buswellii did not grow in agar shakes, the culture was diluted stepwise in liquid medium containing $M$. hungatei. Purity of this binary coculture was checked by growth experiments in medium containing $0.05 \%$ yeast extract, $10 \mathrm{mM}$ benzoate, $10 \mathrm{~m} M$ sulfate, and $5 \mathrm{~m} M$ BES. In this medium, no growth occurred after 6 weeks of incubation. The binary methanogenic coculture grew with $10 \mathrm{~m} M$ benzoate at $28^{\circ} \mathrm{C}$ with a doubling time of 7.2 days $(\mu=0.096$ days $^{-1}$ ) (Fig. 1). S. buswellii also grew independently of

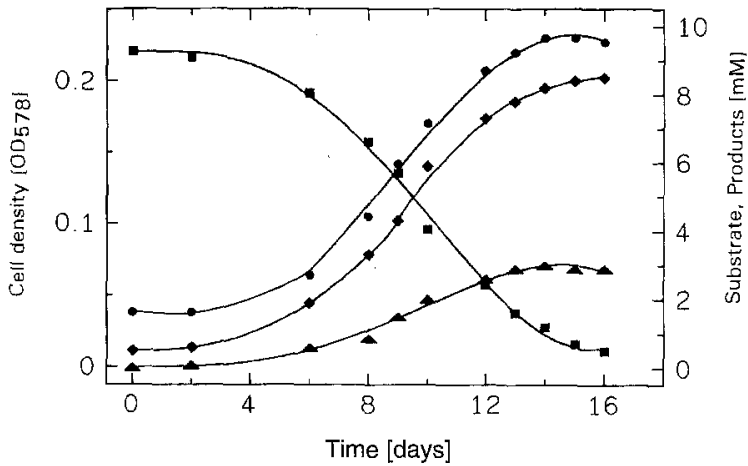

Fig. 1 Growth of Syntrophus buswellii with crotonate as substrate. The mineral medium contained $5 \mathrm{~m} M$ BES; the number of Methanospirillum hungatei cells was lower than $1 \%$ of total cell mass. Symbols: cell density, $\boldsymbol{D}$ crotonate, $\boldsymbol{\Delta}$ butyrate, $\boldsymbol{\Delta}$ acetate

Table 1 Release of butyryl-CoA dehydrogenase by mutanolysin treatment of the Syntrophomonas wolfei/Methanospirillum hungatei coculture and release of fluorescence by mutanolysin treatment of a pure culture of $M$. hungatei

\begin{tabular}{|c|c|c|c|}
\hline \multirow[t]{2}{*}{ Fraction } & \multicolumn{2}{|c|}{$\begin{array}{l}\text { S. wolfei/M. hungatei } \\
\text { Butyryl-CoA } \\
\text { dehydrogenase }\end{array}$} & \multirow{2}{*}{$\begin{array}{l}\text { M. hungatei } \\
\text { Relative } \\
\text { fluoreschence } \\
\text { Total (\%) }\end{array}$} \\
\hline & $\mathrm{U}^{\mathrm{b}}$ & Total (\%) & \\
\hline $\begin{array}{l}\text { French pass } \\
\text { supernatant }\end{array}$ & 0.175 & 100 & 100 \\
\hline $\begin{array}{l}\text { Mutanolysin } \\
\text { supernatant }\end{array}$ & 0.132 & 75.4 & 15 \\
\hline
\end{tabular}

a Relative fluorescence was determined to indicate the release of methanogenic cell material as described in 'Material and methods" ${ }^{\mathrm{b}} \mu \mathrm{mol} \mathrm{min}^{-1}\left(\mathrm{mg}\right.$ protein $\left.{ }^{-1}\right)$

the partner bacteria with crotonate as substrate in the presence of $5 \mathrm{mM}$ BES, at a growth rate of 0.14 day $^{-1}\left(\mathrm{t}_{\mathrm{d}}=4.8\right.$ days), according to the equation:

2 crotonate $^{-}+2 \mathrm{H}_{2} \mathrm{O} \rightarrow 2$ acetate $^{-}+$butyrate $^{-}+\mathrm{H}^{+}$

The methanogenic partner could be diluted out on this substrate to less than $0.1 \%$ of bacterial biomass, but growth in a definite pure culture could not be obtained. Gentisate, hydroquinone, phthalate, pimelate, and cyclohexane carboxylate (each $5 \mathrm{~m} M$ ) were not degraded by the binary methanogenic culture. Sulfate did not serve as alternative electron acceptor.

\section{Selective lysis of $S$. wolfei cells with mutanolysin}

Incubation of a cell suspension of the $S$. wolfei/M. hungatei coculture with mutanolysin resulted in complete lysis of the slightly curved $S$. wolfei cells. Cells of $M$. hungatei remained unaffected and were still motile. In the supernatant of the mutanolysin-treated cell suspension, $75 \%$ of total butyryl-CoA dehydrogenase activity of the crude French press extract was measured (Table 1). Longer incubation resulted in a decrease of the measurable enzyme activities. With a pure culture of $M$. hungatei, the supernatant was 
Table 2 Distribution of butyryl-CoA dehydrogenase, hydrogenase, ATPase and 3-hydroxybutyryl-CoA dehydrogenase after fractionation of crude French press extract of Syntrophomonas wolfei

\begin{tabular}{lllll}
\hline & \multicolumn{2}{l}{ Total activity } & & $(\%)^{\mathrm{a}}$ \\
\cline { 2 - 5 } & $\begin{array}{l}\text { Butyryl-CoA } \\
\text { dehydrogenase }\end{array}$ & $\begin{array}{l}\text { 3-Hydroxybutyryl- } \\
\text { CoA dehydrogenase }\end{array}$ & Hydrogenase & ATPase \\
\hline Cell extract & $100^{\mathrm{a}}$ & $100^{\mathrm{b}}$ & $100^{\mathrm{c}}$ & $100^{\mathrm{d}}$ \\
Soluble fraction & $65-70$ & 80 & $83-95$ & 39 \\
Membrane fraction & $13-18$ & 1 & $8-15$ & 55 \\
\hline
\end{tabular}

$100 \%=0.19 \mu \mathrm{mol} \mathrm{min}^{-1}(\mathrm{mg} \text { protein })^{-1}$

b $100 \%=7.5 \mu \mathrm{mol} \mathrm{min}-1$ (mg protein $)^{-1}$

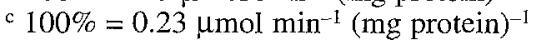

d $100 \%=1.1 \mu \mathrm{mol} \mathrm{min}^{-1}\left(\mathrm{mg}^{2} \text { protein }\right)^{-1}$
Table 3 Distribution of butyryl-CoA dehydrogenase, 3-hydroxybutyryl-CoA dehydrogenase, and hydrogenase after fractionation of crude extract obtained by mutanolysin lysis of Syntrophomonas wolfei

\begin{tabular}{|c|c|c|c|}
\hline & \multicolumn{2}{|l|}{ Total activity } & \multirow{2}{*}{$\frac{(\%)}{\text { Hydrogenase }}$} \\
\hline & $\begin{array}{l}\text { Butyryl-CoA } \\
\text { dehydrogenase }\end{array}$ & $\begin{array}{l}\text { 3-Hydroxybutyryl- } \\
\text { CoA dehydrogenase }\end{array}$ & \\
\hline Cell extract & 100 & 100 & 100 \\
\hline $\begin{array}{l}\text { Soluble } \\
\text { fraction }\end{array}$ & 80 & 91 & 88 \\
\hline $\begin{array}{c}\text { Membrane } \\
\text { fraction }\end{array}$ & 27 & 2 & 15 \\
\hline
\end{tabular}

checked for an increase in fluorescence which would indicate release of the fluorescent methanogenic cofactor $\mathrm{F}_{420}$; the amount of lysis of $M$. hungatei caused by mutanolysin treatment was low compared to the effect of mutanolysin on $S$. wolfei (Table 1). Cells of S. buswellii could not be disintegrated by lysis with mutanolysin or with lysozyme.

\section{Localization of enzyme activities}

Butyryl-CoA dehydrogenase, hydrogenase, 3-hydroxybutyryl-CoA dehydrogenase and ATPase were detected at catabolic activities in crude extract obtained by Frenchpress treatment of the $S$. wolfei/M. hungatei coculture. NAD-dependent 3-hydroxybutyryl-CoA dehydrogenase and ATPase served as control enzymes. Butyryl-CoA dehydrogenase and hydrogenase activities were found to be partially associated with the membrane fraction after French-press treatment of crude extract (Table 2) or mutanolysin treatment (Table 3). On the other hand, 3-hydroxybutyryl-CoA dehydrogenase activity was found exclusively in the cytoplasmic fraction (Tables 2 and 3). The comparably high ATPase activity found in the cytoplasmic fraction could also be due to some extent to soluble phosphatases.

Localization of glutaryl-CoA dehydrogenase in $S$. buswellii was not possible. In crude extracts only low ac-

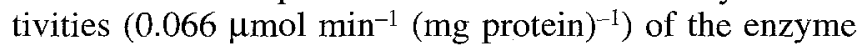
were detected, which could no longer be recovered after further fractionation.

Significant hydrogenase activity was measured in suspensions of intact cells of $S$. wolfei/M. hungatei or $S$.

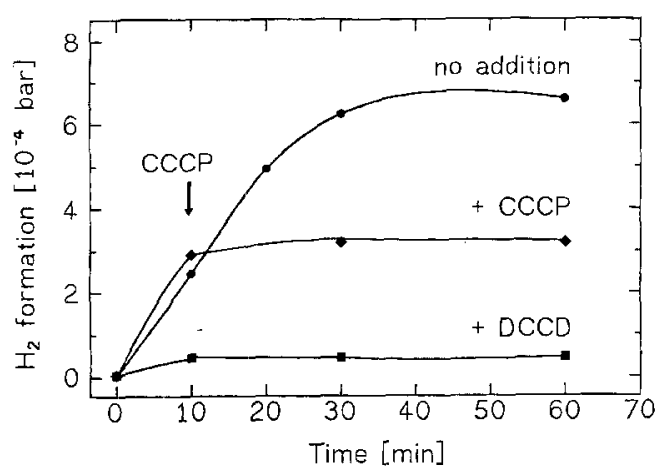

Fig. $2 \mathrm{H}_{2}$ formation in cell suspensions of Syntrophomonas wolfei with $20 \mathrm{~m} M$ butyrate and no inhibitor; after addition of CCCP (10 nmol per mg protein); and $\mathbf{a f t e r}$ preincubation of the cell suspension with DCCD (15 min, $25 \mathrm{nmol}$ per mg protein)

buswellii/M. hungatei cocultures $[0.17$ and $1.1 \mu \mathrm{mol}$ $\mathrm{min}^{-1}$ (mg protein) $)^{-1}$, respectively]. Anoxic incubation of cell suspensions with $1 \mathrm{mM} \mathrm{CuCl}$ as a non-membranepermeating hydrogenase inhibitor resulted in $90-95 \%$ inhibition of the measurable hydrogenase activity in both cocultures. Hydrogenase activity of a pure culture of $M$. hungatei could be measured only in cell extracts and was not detectable with intact cells.

\section{Cytochromes and quinones}

The binary methanogenic cultures of $S$. buswellii and $S$. wolfe $i$ were analyzed for the presence of cytochromes and quinones. No cytochromes could be detected in syntrophically grown cells of $S$. buswellii. $S$. wolfei grown with butyrate also did not contain cytochromes. Both strains contained a menaquinone that, for $S$. wolfei, was identified as menaquinone-7.

\section{Hydrogen release experiments}

Dense suspensions of butyrate-grown cells of $S$. wolfe $i$ formed hydrogen from butyrate at a rate of $2.7 \mathrm{nmol} \mathrm{m^{-1 }}$ (mg protein $)^{-1}$; hydrogen accumulated to a partial pressure of $6.3 \times 10^{-4}$ bar (Fig. 2). Hydrogen was formed from crotonate by crotonate-grown cells of $S$. wolfe $i$ at a rate of $0.6 \mathrm{nmol} \mathrm{m^{-1 }}$ (mg protein) $)^{-1}$, up to a pressure of $7 \times 10^{-4}$ 


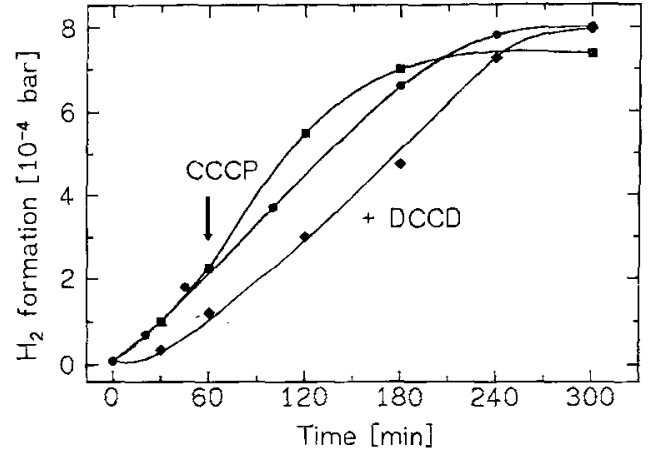

Fig.3 $\mathrm{H}_{2}$ formation in cell suspensions of Syntrophomonas wolfei with $20 \mathrm{~m} M$ crotonate and no inhibitor; $\square$ after addition of CCCP (10 nmol per mg protein); and after preincubation of the cell suspension with DCCD ( $15 \mathrm{~min}, 25 \mathrm{nmol}$ per mg protein)

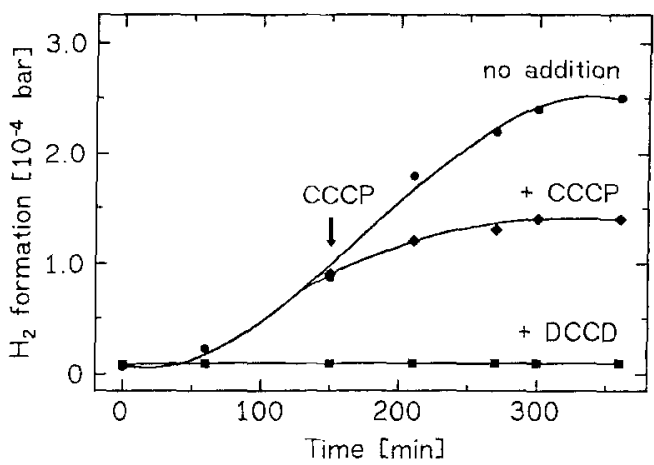

Fig. $4 \mathrm{H}_{2}$ formation in cell suspensions of Syntrophus buswellii with $10 \mathrm{~m} M$ benzoate and no inhibitor; after addition of CCCP (10 nmol per mg protein); and after preincubation of the cell suspension with DCCD (15 min, 25 nmol per mg protein)

bar (Fig. 3). Addition of the protonophore CCCP (25 nmol per mg protein) completely inhibited hydrogen formation from butyrate, whereas CCCP $(\leq 100 \mathrm{nmol}$ per mg protein) had no effect on hydrogen formation from crotonate (Figs. 2 and 3). Similar results were obtained with DCCD; preincubation of butyrate-grown cell suspensions with DCCD (25 nmol per $\mathrm{mg}$ protein) resulted in complete inhibition of hydrogen formation (Fig. 2). Hydrogen formation from crotonate was not affected by DCCD up to 100 nmol per mg protein (Fig. 3). Hydrogen was not formed from crotonate by butyrate-grown cells of $S$. wolfei or from butyrate by crotonate-grown cells.

Cell suspensions of syntrophically grown cells of $S$. buswellii formed hydrogen from benzoate at a rate of 0.43 nmol min $^{-1}$ (mg protein) $)^{-1}$; hydrogen accumulated only up to a pressure of $2.5 \times 10^{-4}$ bar (Fig. 4). Unfortunately, crotonate-grown cells of $S$. buswellii did not form significant amounts of hydrogen from crotonate, so a positive control experiment could not be performed. CCCP (10 nmol per mg protein) and DCCD (25 nmol per mg protein, $15 \mathrm{~min}$ preincubation) completely inhibited hydrogen formation from benzoate. Incubation of the cell suspension with the same amount of absolute ethanol as used in the DCCD and CCCP additions had no influence on the rate and amount of hydrogen formed by any cell suspension.

\section{Dicussion}

New physiological properties of Syntrophus buswellii

Isolation of a binary methanogenic coculture of the syntrophic benzoate-degrading culture S. buswellii made new physiological and biochemical studies possible. Crotonate is dismutated to butyrate and acetate in a manner similar to that observed with Syntrophomonas wolfei (Beaty and McInerney 1987). However, the lag phase for adaptation to the new substrate with benzoate-grown S. buswellii cells was not unusually long; with $S$. wolfei a long lag phase had been observed (Beaty and McInerney 1987). Butyrate-grown cells of $S$. wolfei do not possess crotonylCoA:acetate CoA transferase; therefore, the long lag phase was attributed to the selection of mutants able to activate crotonate (McInerney and Wofford 1992). It seems probable that benzoate-grown cells of $S$. buswellii have the ability to activate crotonate; however, this must be confirmed by enzyme measurements in cell-free extracts of the syntrophically grown culture. A recently isolated syntrophically benzoate-oxidizing bacterium can grow in pure culture with gentisate or hydroquinone as substrate (Szewzyk and Schink 1989; Gorny and Schink 1994).

Evidence of reversed electron transport

In syntrophic butyrate oxidation, electrons are released in two dehydrogenation steps, namely, butyryl-CoA dehydrogenase and 3-hydroxybutyryl-CoA dehydrogenase. The standard redox potential of the former was determined to be $-125 \mathrm{mV}$ (Gustafsson et al. 1986); for the latter the literature gives $-231 \mathrm{mV}$ (Lynen and Wieland 1955) or $-266 \mathrm{mV}$ (Krebs et al. 1962). We redetermined this value by equilibrium measurements with acetoacetyl$\mathrm{CoA}, \mathrm{NADH}$, and 3-hydroxybutyryl-CoA dehydrogenase and found values of $-239 \pm 7 \mathrm{mV}$ (results not shown). This value is close enough to the redox potential of the 2 $\mathrm{H}^{+} / \mathrm{H}_{2}$ couple at $\mathrm{pH} 7.0$ and $\left[\mathrm{H}_{2}\right]$ at $10^{-4} \mathrm{~atm}(-295 \mathrm{mV})$ to allow the assumption that electron transfer from 3-hydroxybutyryl-CoA to protons does not require reversed electron transport; transfer from butyryl-CoA to protons, on the other hand, depends on such an energy-consuming step, which should be driven by, for example, the proton motive force. Such reversed electron transport processes in dissimilatory metabolism have been observed with cell suspensions of Methanosarcina barkeri (Bott and Thauer 1987) and Desulfovibrio vulgaris (Pankhania et al. 1988), as well as with membrane vesicles of the sulfur-reducing Desulfuromonas acetoxidans (Paulsen et al. 1986) or with membrane vesicles of a syntrophically glycolate-oxidizing bacterium (Friedrich and Schink 1993).

Energy-linked electron transport processes require the presence of specific electron transferring proteins and their association with the cytoplasmic membrane. In the present study, mutanolysin proved to be an excellent agent for selective and careful lysis of $S$. wolfei cells in a mixed 
culture with $M$. hungatei. Seventy-five percent of the total activity of butyryl-CoA dehydrogenase of crude Frenchpress extract was released by this method. Similar studies with lysozyme as the selective bacteriolytic agent resulted in a release of only $15.4 \%$ of total 3-hydroxybutyryl-CoA dehydrogenase activity (Wofford et al. 1986). Fluorescence measurements after mutanolysin treatment of $M$. hungate $i$ indicated that the agent had only a slight lytic effect on the methanogenic partner.

Fractionation of the crude extract of $S$. wolfei obtained by mutanolysin lysis or French-press breakage indicated that hydrogenase and butyryl-CoA dehydrogenase activities were at least partially membrane-associated. There was a significant difference in localization between these enzymes and, for example, 3-hydroxybutyryl-CoA dehydrogenase, which was found entirely in the cytoplasm. Obviously, both enzymes are loosely attached to the membrane and may be connected with other transmembrane proteins.

Cells of S. buswellii were completely resistant to bacteriolytical agents, such as lysozyme or mutanolysin, and glutaryl-CoA dehydrogenase activity of crude Frenchpress extracts was lost completely during further fractionation, thus precluding further studies on its localization.

Copper inhibition studies with suspensions of whole cells of $S$. wolfei and S. buswellii indicate that at least part of the hydrogenase activity of both strains is membraneassociated, and that it faces the outer side of the cytoplasmic membrane (Cypionka and Dilling 1986). The fact that in whole cells of a pure culture of $M$. hungatei grown with $\mathrm{H}_{2} / \mathrm{CO}_{2}$, a viologen-dependent hydrogenase activity could not be measured, whereas high activities were detected in crude extracts of this strain, indicates that the membrane of $M$. hungatei is not permeable to oxidized viologen dyes. This is in contrast to results obtained with Desulfovibrio orientis cells (Cypionka und Dilling 1986).

$S$. wolfei and $S$. buswellii both contained significant amounts of a menaquinone. This electron transfer component could be involved in reversed electron transport, but evidence is still lacking. Syntrophically grown cells of the $S$. buswellii/M. hungatei coculture were free of cytochromes. Cells of $S$. wolfei are reported to contain low amounts of a $c$-type cytochrome after growth with crotonate (McInerney and Wofford 1992), but we could not confirm this finding with our culture after syntrophic growth with butyrate. Perhaps the cytochrome plays a role only in crotonate metabolism by this strain.

Unfortunately, we were not able to prepare active inside-out vesicles for direct demonstration of a reversed electron transport either by mutanolysin or by careful French-press treatment of cell suspensions of $S$. wolfei. Therefore, direct evidence of a reversed electron transport in these bacteria had to be sought with suspensions of intact cells. Cell suspensions of $S$. wolfei/M. hungatei cocultures formed low, but significant amounts of hydrogen from butyrate; likewise, cell suspensions of $S$. buswellii/M. hungatei cocultures formed similar amounts of hydrogen from benzoate. Inhibition of this hydrogen formation by low amounts of CCCP or DCCD indicates that butyrate and benzoate conversion to acetate and hydrogen depends on an intact proton potential that is maintained by ATP hydrolysis. For $S$. wolfei, this effect can be confined specifically to butyryl-CoA oxidation because hydrogen formation from crotonate was not affected. Unfortunately, such a positive control experiment was not possible with crotonate-grown cells of $S$. buswellii, and nonspecific effects on, for example, substrate uptake, cannot therefore be ruled out with certainty.

\section{Energetics}

Cells of S. wolfei accumulated $6.3 \times 10^{-4}$ atm or $120 \mu M$ hydrogen from $20 \mathrm{~m} M$ butyrate. According to the stoichiometry of butyrate oxidation by this bacterium,

butyrate $-2 \mathrm{H}_{2} \mathrm{O} \rightarrow 2$ acetate ${ }^{-}+\mathrm{H}^{+}+2 \mathrm{H}_{2}$

acetate concentration should be $120 \mu M$ as well. With these data, the amount of energy in equilibrium with these concentrations can be calculated: $\Delta \mathrm{G}^{\prime}=-26.3 \mathrm{~kJ} / \mathrm{mol} \mathrm{re}-$ action. Obviously, hydrogen and acetate accumulate to a concentration that corresponds thermodynamically with the equivalent of one-third of an ATP unit, which has been defined as the minimum amount of energy required to make ATP (Schink 1990, 1992). This is the amount of energy remaining from 1 ATP formed by substrate-level phosporylation in the acetate kinase reaction (Wofford et al. 1986; Schink 1992) if two-thirds of this ATP unit are invested into translocation of two protons across the cytoplasmic membrane. Two protons could shift the redox potential for two electrons by $165 \mathrm{mV}$ and thus cover exactly the gap between the redox potentials of butyryl-CoA dehydrogenase $(-125 \mathrm{mV})$ and $2 \mathrm{H}^{+} / \mathrm{H}_{2}$ at $10^{-4}$ atm $(-295$ $\mathrm{mV}$ ).

It is too early to speculate on the mechanism of such a reversed electron transport, specifically whether quinones are involved. One could as well construct a model including only consumption of two protons by hydrogenase activity on the outer face of the cytoplasmic membrane and release of two protons by butyryl-CoA dehydrogenation in the cytoplasm, with transfer of electrons from inside outwards. Elucidation of this system will require further studies, provided that active vesicles can be prepared from this bacterium.

Acknowledgements The authors are indebted to Dr. H. Platen, Lich, for redetermining the redox potential of the acetoacetyl$\mathrm{CoA} / 3$-hydroxybutyryl-CoA couple, and to Dr. H. Kroppenstedt, Braunschweig, for analysis of quinones. Fruitful discussions with Dr. R. K. Thauer, Marburg, are appreciated as well. This study was supported by the Bundesministerium für Forschung und Technologie, Bonn, in its program on biological hydrogen formation.

\section{References}

Beaty PS, McInerney MJ (1987) Growth of Syntrophomonas wolfe $i$ in pure culture on crotonate. Arch Microbiol 147:389393

Bergmeyer HU (1974) Methoden der enzymatischen Analyse, 3rd edn. Verlag Chemie, Weinheim 
Bott M, Thauer RK (1987) Proton-motive-force-driven formation of $\mathrm{CO}$ from $\mathrm{CO}_{2}$ and $\mathrm{H}_{2}$ in methanogenic bacteria. Eur $\mathrm{J}$ Biochem 168:407-412

Bradford MM (1976) A rapid and sensitive method for the quantitation of microgram quantities of protein utilizing the principle of protein-dye binding. Anal Biochem 72:248-254

Collins MD (1985) Isoprenoid quinone analyses in bacterial classification and identification. In: Goodfellow M, Minnikin DE (eds) Chemical methods in bacterial systematics. Academic Press, New York London, pp 267-287

Cypionka H, Dilling W (1986) Intracellular localization of the hydrogenase in Desulfotomaculum orientis. FEMS Microbiol Lett $36: 257-260$

Diekert GB, Thauer RK (1978) Carbon monoxide oxidation by Clostridium thermoaceticum and Clostridium formicoaceticum. J Bacteriol 136:597-606

Dolfing J (1988) Acetogenesis. In: Zehnder AJB (ed) Biology of anaerobic microorganisms. Wiley, New York, pp 417-468

Friedrich M, Schink B (1993) Hydrogen formation from glycolate driven by reversed electron transport in membrane vesicles of a syntrophic glycolate-oxidizing bacterium. Eur J Biochem 217 : $233-240$

Gorny N, Schink B (1994) Hydroquinone degradation via reductive dehydroxylation of gentisyl-CoA by a strictly anaerobic fermenting bacterium. Arch Microbiol 161:25-32

Gustafson WG, Feinberg BA, McFarland JT (1986) Energetics of $\beta$-oxidation. Reduction potentials of general fatty acyl-CoA dehydrogenase, electron transfer flavoprotein, and fatty acyl-CoA substrates. J Biol Chem $261: 7733-7741$

Krebs HA, Mellanby J, Williamson DH (1962) The equilibrium constant of the $\beta$-hydroxybutyric-dehydrogenase system. Biochem J 82 : 96-98

Kroppenstedt RM (1985) Fatty acid and menaquinone analysis of actinomycetes and related organisms. In: Goodfellow M, Minnikin DE (eds) Chemical methods in bacterial systematics. Academic Press, New York London, pp 173-199

Lynen F, Wieland O (1955) $\beta$-Ketoreductase. In: Colowick SP, Kaplan NO (eds) Methods in enzymology, vol I. Academic Press, New York London, pp 566-573

McInerney MJ, Wofford NQ (1992) Enzymes involved in crotonate metabolism in Syntrophomonas wolfei. Arch Microbiol $158: 344-349$

McInerney MJ, Bryant MP, Hespell RB, Costerton JW (1981) Syntrophomonas wolfei gen. nov, sp. nov., an anaerobic, syntrophic, fatty-acid oxidizing bacterium. Appl Environ Microbiol 41:1029-1039

Mountfort DO, Brulla WJ, Krumholz LR, Bryant MP (1984) Syntrophus buswellii gen. nov., sp. nov.: a benzoate catabolizer from methanogenic ecosystems. Int J Syst Bacteriol 34:216217

Pankhania IP, Spormann AM, Hamilton WA, Thauer RK (1988) Lactate conversion to acetate, $\mathrm{CO}_{2}$ and $\mathrm{H}_{2}$ in cell suspensions of Desulfovibrio vulgaris (Marburg): indications for the involvement of an energy driven reaction. Arch Microbiol 150: $26-31$
Paulsen J, Kröger A, Thauer RK (1986) ATP-driven succinate oxidation in the catabolism of Desulforomonas acetoxidans. Arch Microbiol 144:78-83

Pfennig N (1978) Rhodocyclus purpureus gen. nov. sp. nov., a ring-shaped, vitamin $B_{12}$-requiring member of the family Rhodospirillaceae. Int J Syst Bacteriol 28:283-288

Platen H. Schink B (1987) Methanogenic degradation of acetone by an enrichment culture. Arch Microbiol 149:136-141

Schink B (1990) Conservation of small amounts of energy in fermenting bacteria. In: Finn RK, Präve P (eds) Biotechnology focus 2. Hanser, München, pp 63-89

Schink B (1992) Syntrophism among procaryotes. In: Balows A, Trüper HG, Dworkin M, Harder W, Schleifer KH (eds) The procaryotes, 2nd edn, vol. 1 Springer, Berlin Heidelberg New York, pp 276-299

Stams AJM, Kremer DR, Nicolay K, Weenk GH, Hansen TA (1984) Pathway of propionate formation in Desulfobulbus propionicus. Arch Microbiol 137:329-337

Szewzyk U, Schink B (1989) Degradation of hydroquinone, gentisate, and benzoate by a fermenting bacterium in pure or defined mixed culture. Arch Microbiol 151:541-545

Thauer RK, Morris JG (1984) Metabolism of chemotrophic anaerobes: old views and new aspects. In: Kelly DP, Carr NG (eds) The microbe 1984, part II. Prokaryotes and eukaryotes. Cambridge University Press, Cambridge, pp 123-168

Thauer RK, Jungermann K, Decker K (1977) Energy conservation in chemotrophic anaerobic bacteria. Bacteriol Rev $41: 100-180$

Tschech A, Pfennig N (1984) Growth yield increase linked to caffeate reduction in Acetobacterium woodii. Arch Microbiol 137: $163-167$

Vogel G, Steinhart R (1976) ATPase of Escherichia coli: purification, dissociation, and reconstitution of the active complex from the isolated subunits. Biochemistry $15: 208-216$

Widdel F, Pfennig N (1981) Studies on dissimilatory sulfate-reducing bacteria that decompose fatty acids. I. Isolation of a new sulfate-reducer enriched with acetate from saline environments. Description of Desulfobacter postgatei gen. nov. sp. nov. Arch Microbiol 129:395-400

Widdel F, Kohring GW, Mayer F (1983) Studies on dissimilatory sulfate-reducing bacteria that decompose fatty acids. III. Characterization of the filamentous gliding Desulfonema limicola gen. nov. sp. nov., and Desulfonema magnum sp. nov. Arch Microbiol 134:286-294

Wofford NQ, Shawn PS, McInerney MJ (1986) Preparation of cell-free extracts and the enzymes involved in fatty acid metabolism in Syntrophomonas wolfei. J Bacteriol 167:179-185

Yokogawa K, Shigeo K, Shinzo I, Yasuhiko I, Yoshio Y (1974) Mutanolysin, bacteriolytic agent for cariogenic streptococci: partial purification and properties. Antimicrob Agents Chemother $6: 156-165$

Zehnder AJB (1978) Ecology of methane formation. In: Mitchell $\mathrm{R}$ (ed) Water pollution microbiology, vol 2. Wiley, London, pp 349-376 